\title{
THE DIVERSITY OF UNDERSTOREY BIRDS IN FOREST FRAGMENTS AND OIL PALM PLANTATION, SARAWAK, BORNEO
}

\section{JAYASILAN MOHD-AZLAN*; VOON AUDREY MEI FANG*; SALLY SOO KAICHEEN*; LISA LOK$^{\star}$ and MICHAEL J LAWES**}

\begin{abstract}
Much of the Bornean rainforest has been converted to oil palm plantation. This has resulted in forest fragmentation, which in turn has led to changes in avian assemblages in these fragments. This study: (1) examines the diversity of understorey birds at the edge, in forest fragments, and in neighbouring oil palm plantation; (2) compares the bird assemblages along distance gradients from the forest edge; 3) identifies the species common to both forest and oil palm plantation; and 4) examines seasonal variation (dry and wet season) in bird diversity. Understorey birds were mist-netted from November 2013 to April 2015 (22 680 net-hours). A total of 342 individuals comprising 58 species from 25 families were captured. Sampling effort did not yield an asymptotic species accumulation curve and an estimated $77 \%$ of all species were captured. Species diversity was greatest at the edge compared to the forest interior and oil palm interior. Species composition differed along the forest-oil palm gradient, with some species confined to the edge, oil palm and forest habitat. Those edge species that also occurred in the oil palm plantation were relatively abundant. Regular surveys of avian assemblage will aid monitoring of habitat quality and change, as well as ecosystem functionality and the maintenance of vital ecosystem services that benefit both native vegetation and oil palm.
\end{abstract}

\section{Keywords: agriculture, avian diversity, conservation, forest fragmentation, High Conservation Value Area, mist-netting}

Date received: 19 March 2019; Sent for revision: 1 April 2019; Received in final form: 5 June 2019; Accepted: 12 July 2019.

\section{INTRODUCTION}

Bornean rainforest is rapidly disappearing and deteriorating under human-mediated pressures, caused especially by land-clearing, logging and the burgeoning expansion of oil palm plantations (Koh, 2007; Gilbert, 2012). In parts of Borneo, rainforest exists only as isolated and fragmented

\footnotetext{
* Animal Resource Science and Management, Faculty of Resource Science and Technology, Universiti Malaysia Sarawak, 94300 Kota Samarahan, Sarawak, Malaysia. E-mail: azlan@unimas.my

** School of Life Sciences, University of KwaZulu-Natal, P/Bag X01, Scottsville 3209, South Africa.
}

secondary forests. Substantial forest conversion and fragmentation have caused an 'extinction debt' resulting in significant biodiversity loss and ongoing extirpation (Aratrakorn et al., 2006; Edwards et al., 2013; Fitzherbert et al., 2008; Koh, 2008a; b; Maas et al., 2009). Fragmented and isolated forest patches are often assumed to have low conservation value because their species communities are depauperate and important ecosystem services may be reduced or absent in small fragments (Miller-Rushing et al., 2019).

Rapid transformation of natural habitats into agricultural lands is a leading global cause of the loss of biodiversity (Myers et al., 2000). Oil palm (Elaeis guineensis) is a rapidly expanding crop and a leading 
cause of deforestation in South-east Asia (Carlson et al., 2013; Srinivas and Koh, 2016). With the exception of Sarawak, oil palm development has almost reached saturation in Malaysia. Sarawak is the final frontier for oil palm development in Malaysia. Oil palm plantation areas in Sarawak expanded from 23000 ha in the 1980s to 840000 ha in 2009 (Cramb and Sujang, 2012). Currently, Sarawak has approximately 1.6 million hectares planted with oil palms, representing $26.9 \%$ of total oil palm plantation area in Malaysia (MPOB, 2018).

The oil palm industry in Malaysia is encouraged to conserve and maintain forest fragments in oil palm plantations, which serve as High Conservation Values Forest (HCVF). HCVF is defined as an area of forest of significant or critical environmental or social importance (Forest Stewardship Council, 2000). These HCVF are monitored to evaluate the environmental and social performance of stakeholders and operators, as well as to ensure that they continue to protect and conserve these areas (Forest Stewardship Council, 2000; Jennings et al., 2003).

Understorey birds are excellent ecological and biodiversity indicators (Bibby et al., 1992; Campbell and Reece, 2002) of the conservation value of tropical rainforest, as they are relatively easy to capture and may specifically portray different types of responses to disturbances (Sekercioglu et al., 2002; Powell et al., 2015); for example, those that typify oil palm conversion areas (Edwards et al., 2014). In addition, monitoring understorey birds can provide early warning of environmental changes (Gregory et al., 2003), as well as important ecosystem services, such as seed dispersal and plant pollination (Sekercioglu et al., 2004; Padoa-Schioppa et al., 2006) and pest control in agricultural environments (Koh, 2008c). Sekercioglu (2006) and Tscharntke et al. (2008) have shown that the loss of birds negatively impacts ecosystem integrity. Therefore, birds can serve as a reliable bio-indicator to monitor habitat quality and changes.

For many organisms in remnant forest patches, the surrounding oil palm dominated landscape presents significant challenges, such as limited food resources and suitable nesting sites (Chazdon et al., 2009). Volant organisms (bats, birds and insects) are less affected by extensive oil palm in the matrix than sedentary organisms (Tscharntke et al., 2008; Turner and Foster, 2009). Tscharntke et al. (2008) argued that in tropical agroforest ecosystems the preservation of natural communities, low-intensity agriculture, and heterogeneous landscapes were critical to the preservation of beta diversity. In general, bird and insect composition were more similar when compared among the same agricultural system than the same natural habitats, and less biodiverse in simple tropical landscapes, especially in monocultures (oil palm) (Tscharntke et al., 2008; Turner and Foster, 2009). Edwards et al. (2010) demonstrated that the persistence of functional bird and insect communities depended on the size of their forest refugia and how extensively and contiguously oil palm was planted in the matrix (see also Koh, 2008b). They recommended retaining large contiguous stands of forest in large oil palm estates, instead of only the small forest on commercially unattractive land (i.e. on steep slopes, in swamps or narrow riparian habitat). Others have suggested that future expansion of oil palm agriculture should now be restricted to pre-existing cropland or degraded habitats (Koh, 2008a).

Land-sharing practices to make oil palm estates more wildlife-friendly have met with mixed success, largely because the land spared is not large enough (Pardo et al., 2018), whether comprising primary or secondary habitat, to adequately support wildlife (Edwards et al., 2010). Consequently, wildlife diversity converges on the composition that can be supported only in the oil palm matrix (Edwards et al., 2013). For most forest-dependent wildlife, the boundary of the oil palm plantation is a hard border that most forest-dependent species do not cross. Very few species, mostly generalists, can live within oil palm plantation under the current management regimes - for these species the oil palm presents a softer boundary, but whether there are sufficient of these species to maintain vital ecosystem services such as nutrient regulation is unknown (Mayfield, 2005; Foster et al., 2011).

Using understorey birds, which have previously been shown to be good indicators of fragmentation effects (Yahner, 1988; Newmark, 1991; Krüger and Lawes, 1997), we examine their assemblage structure within oil palm plantation, determine how their diversity is affected by forest fragmentation, as well as changes to potential ecosystem services (Koh, 2008c) in forest fragments. The objectives of the present study were: (1) to investigate the diversity and understorey bird assemblage in a forest fragment-extensive oil palm mosaic landscape; (2) to compare understorey bird assemblage structure and turnover along a disturbance gradient from the interior of forest fragments, through the ecotone between forest and oil palm, into established oil palm plantation; (3) to determine what species can survive in oil palm and what species are filtered out at the oil palm edge; and (4) to examine possible seasonal bird diversity trends from the forest interior, across the ecotone into oil palm. Our study assists in predicting the pattern of decline of the bird assemblage in the understorey of forest fragments surrounded by oil palm and provides recommendations to improve the wildlife-friendly management of oil palm plantations. 


\section{MATERIAL AND METHODS}

\section{Study Area}

This study was carried out at PPB Oil Palms Berhad $\left(1.5533^{\circ} \mathrm{N}, 110.3592^{\circ} \mathrm{E}\right)$, an oil palm plantation (20 360 ha) located between Bintulu and Miri, Sarawak in Malaysia. The surveys were conducted in the oil palm plantation (20 years old, planted in 1995) adjacent to two HCVF fragments (116.28 and 989.86 ha) with different topography and elevation (Figure 1). The smaller forest fragment (Fragment 1 ) is roughly $800 \mathrm{~m}$ wide by $1.5 \mathrm{~km}$ long. The larger forest fragment (Fragment 2) is a narrow (700 m wide) strip (14 km long) of steep forest (slope $=35^{\circ}$ ) with difficult access. Some economically important dipterocarp trees (Anisoptera spp., Shorea spp., Dryobalanops spp., and Dipterocarpus spp.) and non-dipterocarp species (Artocarpus spp., and Eusideroxylon zwageri) can be found in these forest fragments.

\section{Data Collection}

A total of six mist-netting sampling periods were conducted non-continuously from November 2013 to April 2015 in three ecotypes - the interior of forest fragments, the oil palm plantation, and the ecotone.
The ecotone was defined as forest edge between forest fragments and oil palm plantation. The ecotone is the frontier of sudden change between habitats and the biodiversity at this ecotone is presumed to contain species from both the adjacent habitat types (Potts et al., 2016). In each sampling period, three transect lines were chosen and seven mist nets (9 $\mathrm{m} \times 12.6 \mathrm{~m}$, with $36 \mathrm{~mm}$ mesh) were set along each transect line to total 21 mist-nets per sampling period; one mist-net at the edge, and three each in the forest interior and in the adjacent oil palm plantation. In the oil palm plantation and the forest interior, the three mist-nets were set at $300 \mathrm{~m}, 200 \mathrm{~m}$ and $100 \mathrm{~m}$ from the edge. Transects were at least $100 \mathrm{~m}$ apart. The first three sampling periods were conducted in $\mathrm{HCV}$ Fragment 1 while another three sampling periods were conducted afterwards in HCV Fragment 2. A total of 22680 net-hours were completed. Sampling effort was different at each HCV fragment; Fragment 1 was sampled for 9576 net-hours; Fragment 2 for 13104 net-hours. Nets were open throughout day and night and were checked every $2 \mathrm{hr}$. Captured species were identified and measured and the location of the bird was recorded. Individuals were banded before being released approximately $30 \mathrm{~min}$ after being removed from the net, near the site of capture. The birds captured in this way were largely from the understorey guild.

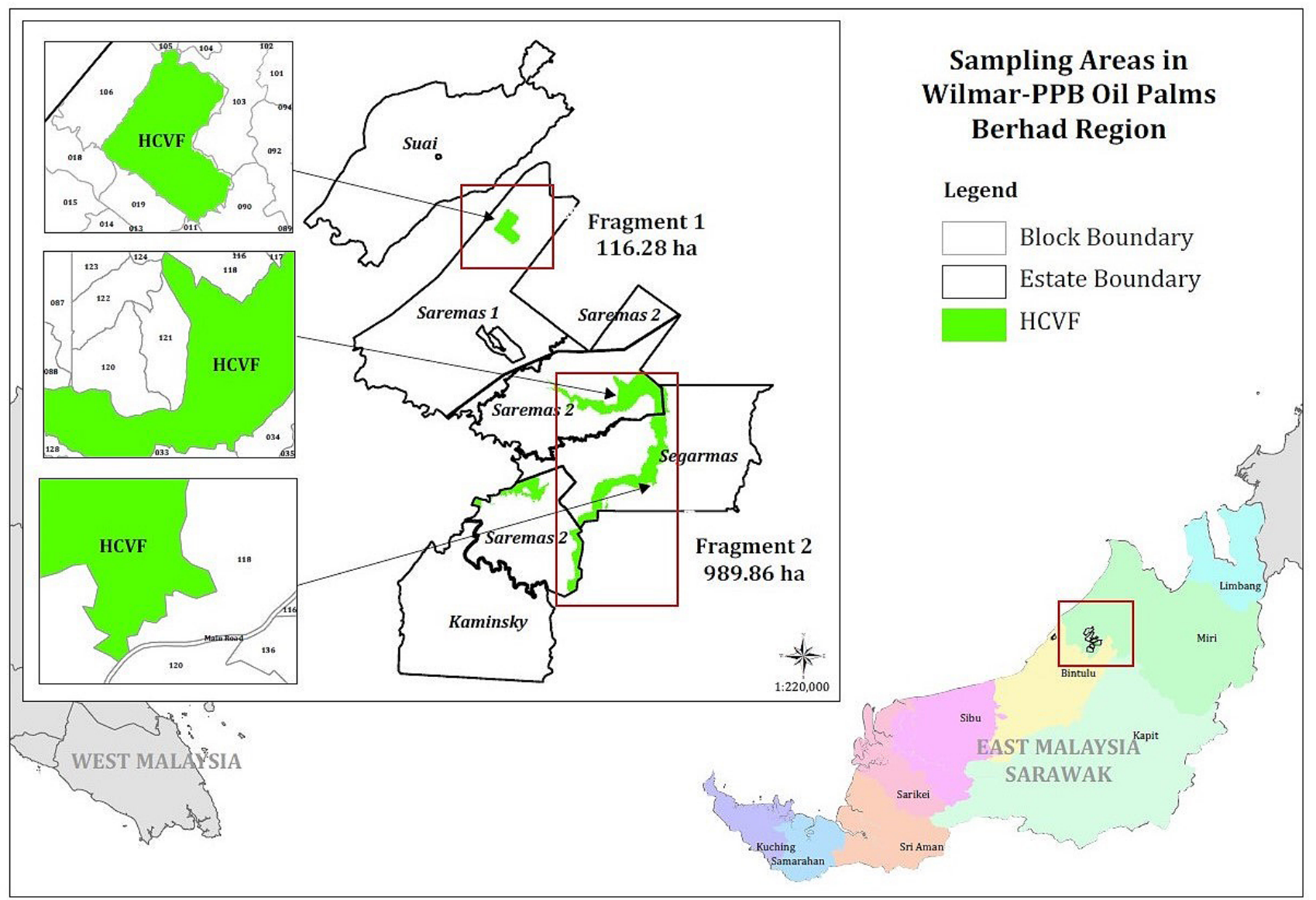

Figure 1. Sampling areas in Wilmar-PPB Oil Palms Berhad regions. Boxes around the map represent enlarged views of each study area showing the location of sampling sites on forest cover (green) and oil palm plantation (white). 


\section{Data Analyses}

Avian species diversity at the edge, between $\mathrm{HCV}$ forest fragments, among habitats (forest and oil palm plantation), distance from the edge (300 $\mathrm{m}, 200 \mathrm{~m}, 100 \mathrm{~m}$ into both habitats), and seasonal diversity trends were analysed. Transient species (e.g. migrants and vagrants) were excluded from the analyses. Shannon's diversity index $\left(\mathrm{H}^{\prime}\right)$, calculated using the natural log, was used because it differentiates between communities and is less sensitive to sample size than other indices (Magurran, 2004). The evenness index $\left(E_{H}\right)$ was used to determine the evenness among species within the community. The number of individuals per species is assumed to be even or similar when $\mathrm{E}_{\mathrm{H}}$ is larger (Mulder et al., 2004). It is widely used in determining the dominant and less dominant species in the community. All analyses were computed using EstimateS Version 9 (Colwell, 2013) and PAST (Paleontological Statistics) Version 3.2 (Hammer et al., 2001) statistical software. Kruskal-Wallis tests for significant differences in avian diversity among habitat types, distance to edge and seasonality, were computed using SPSS Statistics for Windows, Version 20.0. For seasonal effects, the data were categorised as wet season (October to March) and dry season (April to September) and the Wilcoxon signed-rank test was used to analyse these data.

\section{RESULTS}

A total of 338 individuals comprising 56 species from 25 families were captured in 22680 net-hours (45 sampling days; Table 1). Transient species such as the Siberian Blue Robin were excluded from further analysis. The largest number of species was represented by the family Pynonotidae, comprising nine bulbul species; followed by Nectariniidae ( $\mathrm{n}=$ 6 species) $\mathrm{H}^{\prime}$ for all birds was 3.35 and $\left(\mathrm{E}_{\mathrm{H}}\right)$ was 0.51 . Little Spiderhunter with 43 individuals $(12.7 \%)$ was the most caught species, followed by the Oriental Magpie Robin ( $\mathrm{n}=38,11.2 \%)$ and Oriental DwarfKingfisher $(\mathrm{n}=36,10.7 \%)$. The conservation status of 44 species $(78.6 \%$ ) was 'Least Concern (LC)', while 11 species $(19.64 \%)$ were 'Near Threatened (NT)' (IUCN, 2019). Eight species $(13.79 \%$ ) are protected under the Wild Life Protection Ordinance (1998) of Sarawak.

One hundred and sixty individuals from 34 species were captured in the forest; 52 individuals from 26 species at the edge, and 126 individuals from 28 species in the oil palm plantation. In forest, the most abundant species was the Oriental Dwarfkingfisher $(n=30)$, then the Litter Spiderhunter $(n=26)$, White-rumped Shama $(n=13)$ and Yellowbellied Bulbul $(n=10)$. The most abundant species recorded at both the edge and in oil palm plantation was the Oriental Magpie Robin, comprising six and 27 individuals, respectively. Four species of owls were captured: Brown Wood Owl ( $n=1)$ in the forest; Oriental Bay Owl $(n=1)$ and Sunda Scops Owl $(n=1)$ at the edge; and the Reddish Scops Owl $(n=3)$ and Sunda Scops Owl $(n=5)$ in the oil palm plantation. Owl species represented $3.5 \%$ of all the individuals and $8.6 \%$ of the bird species caught in this study. Three species endemic to Borneo were recorded: Yellow-rumped Flowerpecker, Dusky Munia and Bornean Whistler.

Species accumulation curves did not asymptote but gradually increased until the $43^{\text {rd }}$ sampling day (Figure 2), suggesting additional sampling may yielded more understorey birds. The overall expected species richness (Chao 2) was 73 species and sampling saturation was moderate (completeness ratio $=0.77$ ).

Sampling saturation was lower in the forest (completeness ratio $=0.68$ ) and the edge (completeness ratio $=0.60$ ) compared to the oil palm (completeness ratio $=0.83$ ) .

In the smaller, but more circular forest Fragment 1, 181 individuals from 42 species were captured. In the much larger, but longer and narrower forest Fragment 2, only 157 individuals from 37 species were recorded. Species diversity in these HCV forest fragments were marginally different $(\mathrm{t}=1.956, \mathrm{p}=0.051)$. Forest Fragment $1 \quad\left(\mathrm{H}^{\prime}=3.26\right)$ had greater bird diversity compared to forest Fragment $2\left(\mathrm{H}^{\prime}=3.04\right)$. The assemblage structure and composition were more even in Fragment $1\left(\mathrm{E}_{\mathrm{H}}=\right.$ 0.62) than in the larger forest Fragment $2\left(\mathrm{E}_{\mathrm{H}}=0.56\right)$.

Bird diversity was greater at the edge $\left(\mathrm{H}^{\prime}=3.09\right)$ than in the forest $\left(\mathrm{H}^{\prime}=2.94\right)$ and oil palm plantation $\left(\mathrm{H}^{\prime}=2.90\right)$. Species abundances were more evenly partitioned at the edge $\left(\mathrm{E}_{\mathrm{H}}=0.85\right)$ than in the forest interior $\left(\mathrm{E}_{\mathrm{H}}=0.56\right)$ and oil palm plantation $\left(\mathrm{E}_{\mathrm{H}}=0.65\right)$. Seventeen bird species were exclusively caught in forest, 10 species exclusively in oil palm plantation and five species only at the edge. Some species were recorded in both ecotypes or/and at the edge. For example, three species (Short-tailed Babbler, Spectacled Bulbul and Striped Tit-Babbler) were recorded in both the forest and oil palm plantation; five species (e.g. Purple-naped Sunbird, Cream-vented Bulbul, Redeyed Bulbul) occurred in both the forest interior and at the edge; and six species (e.g. Yellow-vented Bulbul, Brown-throated Sunbird, Black-capped Babbler) occurred at both the edge and in oil palm plantation (Table 1). Ten species occurred throughout the distance gradient in both habitat types and at the edge (Table 1). Of these, most of the carnivorous avian species $(n=6)$ were recorded at the edge, while most species of insectivorous $(n=15)$ and omnivorous $(n=17)$ were recorded in the forest. Conversely, the omnivorous birds recorded as major guild in the forest $(n=17)$, while insectivorous birds as major guild in the oil palm plantation $(n=14)$ and at the edge $(n=11)$. The frugivorous and nectarivorous 
TABLE 1. BIRD SPECIES ACCOUNTED AND INDIVIDUAL CAPTURED BY USING MIST-NETTING IN SAREMAS OIL PALM AREA, MIRI, SARAWAK FROM YEAR 2013-2015

\begin{tabular}{|c|c|c|c|c|c|c|c|c|}
\hline Family & Common name & Species name & Guild & Forest & Edge & $\begin{array}{c}\text { Oil } \\
\text { palm } \\
\text { plantation }\end{array}$ & $\begin{array}{c}\text { Total } \\
\text { (n) }\end{array}$ & $\begin{array}{l}\text { IUCN } \\
(2018)\end{array}$ \\
\hline Accipitridae & Crested Serpent-eagle & Spilornis cheela (Latham, 1790) & C & 0 & 1 & 0 & 1 & $\mathrm{LC}$ \\
\hline \multirow[t]{3}{*}{ Alcedinidae } & Blue-eared Kingfisher & Alcedo meninting (Horsfield, 1821) & C & 3 & 1 & 3 & 7 & $\mathrm{LC}$ \\
\hline & $\begin{array}{l}\text { Rufous-backed Kingfisher/ } \\
\text { Oriental Dwarf-kingfisher }\end{array}$ & Ceyx erithaca (Linnaeus, 1758) & $\mathrm{C}$ & 30 & 3 & 3 & 36 & $\mathrm{LC}$ \\
\hline & Rufous-collared Kingfisher & Actenoides concretus (Temminck, 1825) & $\mathrm{C}$ & 5 & 1 & 0 & 6 & NT \\
\hline \multirow[t]{2}{*}{ Apodidae } & Black-nest Swiftlet & Aerodramus maximus (Hume, 1878) & I & 0 & 1 & 1 & 2 & LC \\
\hline & Glossy Swiftlet & Collocalia esculenta (Linnaeus, 1758) & I & 0 & 2 & 5 & 7 & LC \\
\hline Cisticolidae & Yellow-bellied Prinia & Prinia flaviventris (Delessert, 1840) & I & 0 & 0 & 2 & 2 & LC \\
\hline \multirow{2}{*}{$\begin{array}{l}\text { Columbidae } \\
\text { Corvidae }\end{array}$} & Common Emerald Dove & Chalcophaps indica (Linnaeus, 1758) & $\mathrm{O}$ & 7 & 3 & 5 & 15 & LC \\
\hline & Malay Black Magpie & Platysmurus leucopterus (Temminck, 1824) & $\mathrm{O}$ & 1 & 0 & 0 & 1 & NT \\
\hline \multirow[t]{3}{*}{ Dicaeidae } & $\begin{array}{l}\text { Crimson-breasted } \\
\text { Flowerpecker }\end{array}$ & $\begin{array}{c}\text { Prionochilus percussus (Temminck } \mathcal{E} \\
\text { Laugier, 1826) }\end{array}$ & $\mathrm{O}$ & 1 & 0 & 0 & 1 & $\mathrm{LC}$ \\
\hline & Orange-bellied & Dicaeum trigonostigma (Scopoli, 1786) & $\mathrm{F} / \mathrm{N}$ & 0 & 0 & 2 & 2 & LC \\
\hline & $\begin{array}{l}\text { Yellow-rumped } \\
\text { Flowerpecker }\end{array}$ & Prionochilus xanthopygius (Salvadori, 1868) & $\mathrm{O}$ & 0 & 0 & 2 & 2 & $\mathrm{LC}$ \\
\hline \multirow[t]{2}{*}{ Estrildidae } & Black-headed Munia & Lonchura malacca (Linnaeus, 1766) & $\mathrm{F} / \mathrm{N}$ & 0 & 0 & 1 & 1 & LC \\
\hline & Dusky Munia & Lonchura fuscans (Cassin, 1852) & $\mathrm{F} / \mathrm{N}$ & 0 & 0 & 5 & 5 & $\mathrm{LC}$ \\
\hline Eurylaimidae & Green Broadbill & Calyptomena viridis (Raffles, 1822) & $\mathrm{F} / \mathrm{N}$ & 1 & 0 & 0 & 1 & NT \\
\hline Locustellidae & Striated grassbird & Megalurus palustris (Horsfield, 1821) & I & 0 & 1 & 0 & 1 & $\mathrm{LC}$ \\
\hline Megalaimidae & Red-throated Barbet & Psilopogon mystacophanos (Temminck, 1824) & $\mathrm{O}$ & 1 & 0 & 0 & 1 & NT \\
\hline Meropidae & Blue-throated Bee Eater & Merops viridis (Linnaeus, 1758) & I & 0 & 0 & 2 & 2 & LC \\
\hline \multirow[t]{6}{*}{ Nectariniidae } & Brown-throated Sunbird & Anthreptes malacensis (Scopoli, 1786) & $\mathrm{F} / \mathrm{N}$ & 0 & 1 & 3 & 4 & $\mathrm{LC}$ \\
\hline & Crimson Sunbird & Aethopyga siparaja (Raffles, 1822) & I & 2 & 3 & 1 & 6 & LC \\
\hline & Little Spiderhunter & Arachnothera longirostra (Latham, 1790) & $\mathrm{O}$ & 26 & 3 & 14 & 43 & $\mathrm{LC}$ \\
\hline & Plain Sunbird & Anthreptes simplex (Müller, 1843) & $\mathrm{O}$ & 0 & 0 & 1 & 1 & $\mathrm{LC}$ \\
\hline & Purple-naped Sunbird & Arachnothera hypogrammica (Müller, 1843) & $\mathrm{O}$ & 6 & 1 & 0 & 7 & LC \\
\hline & Purple-throated Sunbird & Leptocoma sperata (Linnaeus, 1766) & $\mathrm{F} / \mathrm{N}$ & 0 & 1 & 0 & 1 & $\mathrm{LC}$ \\
\hline Pachycephalidae & Bornean Whistler & Pachycephala hypoxantha (Sharpe, 1887) & $\mathrm{O}$ & 1 & 0 & 0 & 1 & $\mathrm{LC}$ \\
\hline \multirow[t]{4}{*}{ Pellorneidae } & Ferruginous Babbler & Trichastoma bicolor (Lesson, 1839) & I & 2 & 0 & 0 & 2 & LC \\
\hline & Rufous-crowned Babbler & Malacopteron magnum (Eyton,1839) & I & 1 & 0 & 0 & 1 & NT \\
\hline & Scaly-crowned Babbler & Malacopteron cinereum (Eyton, 1839) & $\mathrm{O}$ & 1 & 0 & 0 & 1 & $\mathrm{LC}$ \\
\hline & Short-tailed Babbler & Trichastoma malaccense (Hartlaub, 1844) & I & 1 & 0 & 1 & 2 & NT \\
\hline \multirow[t]{2}{*}{ Picidae } & Maroon Woodpecker & Blythipicus rubiginosus (Swainson, 1837) & I & 2 & 0 & 0 & 2 & $\mathrm{LC}$ \\
\hline & Rufous Piculet & Sasia abnormis (Temminck, 1825) & I & 1 & 1 & 0 & 2 & $\mathrm{LC}$ \\
\hline \multirow[t]{9}{*}{ Pycnonotidae } & Cream-vented Bulbul & Pycnonotus simplex (Lesson, 1839) & $\mathrm{O}$ & 1 & 2 & 0 & 3 & $\mathrm{LC}$ \\
\hline & Brown-cheeked Bulbul & Alophoixus bres (Lesson, 1832) & I & 1 & 0 & 0 & 1 & $\mathrm{LC}$ \\
\hline & Hairy-backed Bulbul & Tricholestes criniger (Blyth, 1845) & $\mathrm{O}$ & 7 & 0 & 0 & 7 & $\mathrm{LC}$ \\
\hline & Olive-winged Bulbul & Pycnonotus plumosus (Blyth, 1845) & $\mathrm{O}$ & 4 & 3 & 9 & 16 & LC \\
\hline & Puff-backed Bulbul & Euptilotus eutilotus (Jardine E Selby, 1837) & $\mathrm{O}$ & 1 & 0 & 0 & 1 & NT \\
\hline & Red-eyed Bulbul & Pycnonotus brunneus (Blyth, 1845) & $\mathrm{O}$ & 3 & 3 & 0 & 6 & $\mathrm{LC}$ \\
\hline & Spectacled Bulbul & Pycnonotus erythropthalmos (Hume, 1878) & $\mathrm{O}$ & 4 & 0 & 3 & 7 & $\mathrm{LC}$ \\
\hline & Yellow-bellied Bulbul & Alophoixus phaeocephalus (Hartlaub, 1844) & $\mathrm{O}$ & 10 & 0 & 0 & 10 & $\mathrm{LC}$ \\
\hline & Yellow-vented Bulbul & Pycnonotus goiavier (Scopoli, 1786) & $\mathrm{O}$ & 0 & 3 & 7 & 10 & $\mathrm{LC}$ \\
\hline Rallidae & White-breasted Waterhen & Amaurornis phoenicurus (Pennant, 1769) & $\mathrm{O}$ & 0 & 0 & 1 & 1 & $\mathrm{LC}$ \\
\hline Rhipiduridae & Sunda Pied Fantail & Rhipidura javanica (Sparrman, 1788) & I & 2 & 1 & 5 & 8 & $\mathrm{LC}$ \\
\hline \multirow[t]{3}{*}{ Strigidae } & Brown Wood-Owl & Strix leptogrammica (Temminck, 1831) & C & 1 & 0 & 0 & 1 & LC \\
\hline & Sunda Scops-Owl & Otus lettia (Hodgson, 1836) & $\mathrm{C}$ & 0 & 1 & 5 & 6 & LC \\
\hline & Reddish Scops-Owl & Otus rufescens (Horsfield, 1821) & $\mathrm{C}$ & 0 & 0 & 3 & 3 & NT \\
\hline \multirow[t]{2}{*}{ Sylviidae } & Ashy Tailorbird & Orthotomus ruficeps (Lesson, 1830) & I & 0 & 0 & 1 & 1 & LC \\
\hline & Rufous-tailed Tailorbird & Orthotomus sericeus (Temminck, 1836) & I & 3 & 3 & 7 & 13 & LC \\
\hline
\end{tabular}


TABLE 1. BIRD SPECIES ACCOUNTED AND INDIVIDUAL CAPTURED BY USING MIST-NETTING IN SAREMAS OIL PALM AREA, MIRI, SARAWAK FROM YEAR 2013-2015 (continued)

\begin{tabular}{|c|c|c|c|c|c|c|c|c|}
\hline Family & Common name & Species name & Guild & Forest & Edge & $\begin{array}{c}\text { Oil } \\
\text { palm } \\
\text { plantation }\end{array}$ & $\begin{array}{c}\text { Total } \\
\text { (n) }\end{array}$ & $\begin{array}{l}\text { IUCN } \\
(2018)\end{array}$ \\
\hline \multirow[t]{4}{*}{ Timaliidae } & Black-capped Babbler & Pellorneum capistratum (Temminck, 1823) & I & 0 & 2 & 1 & 3 & $\mathrm{LC}$ \\
\hline & Black-throated Babbler & Stachyris nigricollis (Temminck, 1836) & I & 5 & 0 & 0 & 5 & NT \\
\hline & Chestnut-rumped Babbler & Stachyris maculata (Temminck, 1836) & I & 2 & 0 & 0 & 2 & NT \\
\hline & Bold Striped Tit-Babbler & Mixornis bornensis (Bonaparte, 1850) & I & 3 & 0 & 1 & 4 & $\mathrm{LC}$ \\
\hline Trogonidae & Diard's Trogon & Harpactes diardii (Temminck, 1832) & $\mathrm{O}$ & 3 & 0 & 0 & 3 & NT \\
\hline \multirow{3}{*}{ Turdidae } & Oriental Magpie Robin & Copsychus saularis (Linnaeus, 1758) & I & 5 & 6 & 27 & 38 & $\mathrm{LC}$ \\
\hline & White-crowned Shama & $\begin{array}{c}\text { Copsychus stricklandii (Motley } \mathcal{E} \\
\text { Dillwyn, 1855) }\end{array}$ & I & 0 & 1 & 0 & 1 & $\mathrm{DD}$ \\
\hline & White-rumped shama & Kittacincla malabarica (Scopoli, 1788) & I & 13 & 3 & 5 & 21 & LC \\
\hline \multirow[t]{4}{*}{ Tytonidae } & Oriental Bay Owl & Phodilus badius (Horsfield, 1821) & $\mathrm{C}$ & 0 & 1 & 0 & 1 & $\mathrm{LC}$ \\
\hline & Total species & & & 34 & 26 & 28 & & \\
\hline & Number of families & & & 17 & 14 & 16 & & \\
\hline & Diversity $\mathrm{H}^{\prime}$ & & & 2.94 & 3.09 & 2.9 & & \\
\hline Evenness & & & & 0.56 & 0.85 & 0.65 & & \\
\hline
\end{tabular}

Note: Bird's family indicated in bold. Guild: C- carnivores, I - insectivores, O - omnivores, and F/N- frugivores and nectarivores. Status: $\mathrm{R}$ - resident and M - migrant. International Union for Conservation of Nature (IUCN) status: LC - least concern, NT- near threatened, DD - data deficient.

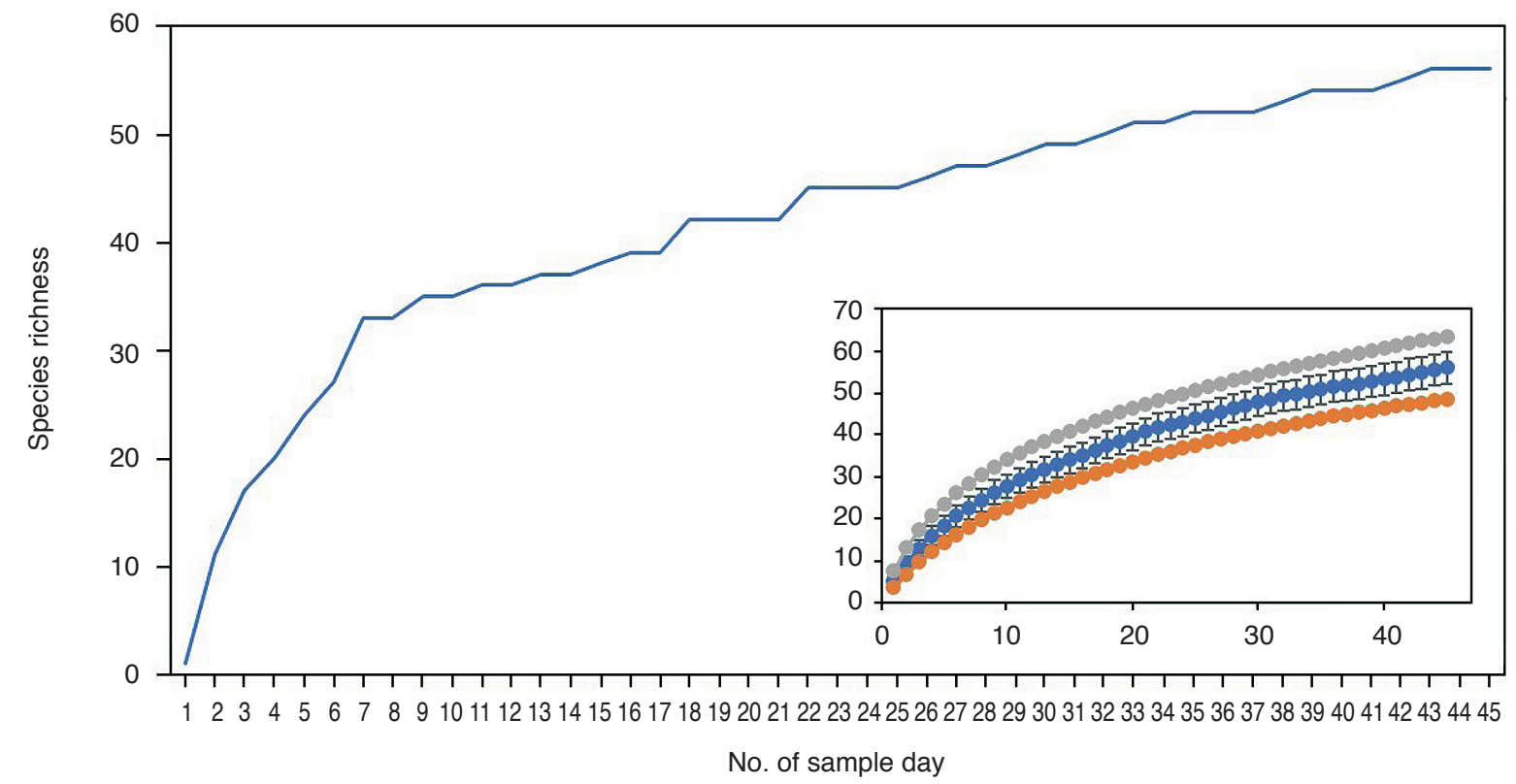

Figure 2. Species accumulation curve with number of individuals captured during sampling period. Insert: Rarefaction curve with $95 \%$ confidence intervals for bird species recorded by using mist-netting method. Blue line indicated the observed value; orange line indicates lower limits and grey line indicates upper limits.

birds appeared as smallest guild throughout the distance gradients (F: $n=1 ; E: n=2 ;$ OPP: $n=4)$.

The species composition along the distance gradient also varied (Table 2). The greatest species richness was recorded at the edge $(\mathrm{S}=26)$, and then at $200 \mathrm{~m}$ into the forest $(\mathrm{S}=22)$ (Figure 3 ). The lowest number of species was recorded at $100 \mathrm{~m}$ into the forest with only 15 species (41 individuals). The most individuals $(n=68)$ was captured at $200 \mathrm{~m}$ into the forest, then at the edge $(n=52)$ and at 300 $m$ into the forest $(n=51)$. The lowest number of individuals was captured $100 \mathrm{~m}$ into the oil palm plantation with 38 individuals and 18 species only. At the distance of $200 \mathrm{~m}$ and $300 \mathrm{~m}$ into the oil palm plantation, 17 species were recorded with 41 individuals and 47 individuals respectively. Besides the edge, $200 \mathrm{~m}$ forest $\left(\mathrm{H}^{\prime}=2.81\right)$ had greater species diversity, while $100 \mathrm{~m}$ into the forest presented the lowest diversity $\left(\mathrm{H}^{\prime}=2.45\right)$ (Figure 3). There was a significant difference in median species richness 
TABLE 2. BIRD DIVERSITY INDICES ESTIMATES FOR DIFFERENT DISTANCE GRADIENT FROM FOREST FRAGMENT TO OIL PALM PLANTATION

\begin{tabular}{lccccccc}
\hline Distance gradient & F300 & F200 & F100 & Edge & OP100 & OP200 & OP300 \\
\hline Number of species $(\mathrm{S})$ & 18 & 22 & 15 & 26 & 18 & 17 & 17 \\
Number of individual $(\mathrm{n})$ & 51 & 68 & 41 & 52 & 38 & 41 & 47 \\
Shannon's diversity index $\left(\mathrm{H}^{\prime}\right)$ & 3.09 & 2.81 & 2.45 & 3.09 & 2.54 & 2.56 & 2.55 \\
Evenness index $\left(\mathrm{E}_{\mathrm{H}}\right)$ & 0.85 & 0.76 & 0.78 & 0.85 & 0.70 & 0.76 & 0.75 \\
\hline
\end{tabular}

Note: F100 -100 m into forest; F200 - 200 m into forest; F300 - 300 m into forest; edge - forest-oil palm edge; OP100 - 100 m into oil palm plantation; OP200 - $200 \mathrm{~m}$ into oil palm plantation; OP300 - $300 \mathrm{~m}$ into oil palm plantation.

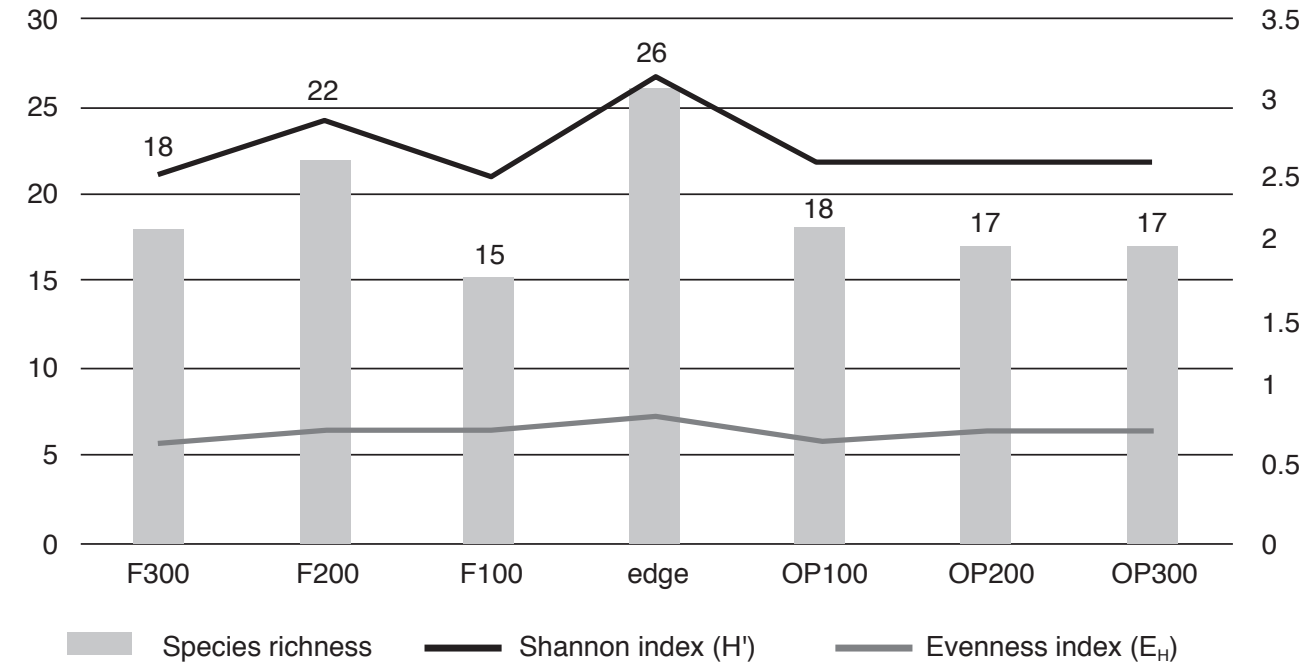

Figure 3. Diversity indices of mist-net capture for gradient distance from forest to oil palm plantation. Species richness indicated on top of the bar, evenness (-) and diversity indices (--) of mist-net capture for gradient distance from forest to oil palm plantation. F100 - $100 \mathrm{~m}$ into forest; F200 - $200 \mathrm{~m}$ into forest; F300 - 300 m into forest; edge - edge; OP100 - 100 m into oil palm plantation; OP200 - $200 \mathrm{~m}$ into oil palm plantation; OP300 - $300 \mathrm{~m}$ into oil palm plantation.

across the distance gradient $\left[\mathrm{x}^{2}(3)=8.28, \mathrm{p}<0.05\right]$. Additionally, post-hoc tests revealed a significant difference in median richness between the edge and $200 \mathrm{~m}$ into the forest $(\mathrm{p}=0.036)$.

Both species richness and bird abundance did not differ significantly between seasons. However, more species were recorded during the dry season in the month of April in the forest.

\section{DISCUSSION}

Oil palm presents a relatively hard barrier to movement by forest-dependent bird species. The diversity of bird species was greatest at the forest edge, where understorey bird species mixed with matrix generalists in ecotonal habitat. Of the 28 species recorded in the oil palm matrix, 10 species were restricted to the matrix, indicating that oil palm habitat is not able to support most forest species in this study. Those forest species that did use the oil palm habitat were mostly understorey insectivores. Another worrying finding is that in spite of its considerably larger size, Fragment 2 had fewer species than Fragment 1. It is possible that the narrow linear shape of Fragment 2 creates pervasive edge effects, which exclude some forest species. These findings are largely consistent with other studies of avian diversity in tropical forest-oil palm landscape mosaics (Amit et al., 2014; Aratrakorn et al., 2006; Azhar et al., 2011; Azman et al., 2011; Edwards et al., 2013; Koh, 2008a; Maas et al., 2009; Peh et al., 2006; Puan et al., 2011; Sheldon et al., 2010; Tscharntke et al., 2008).

Most of the bird species recorded in the oil palm plantation were generalists with wide dietary bread th. The latter is commensurate with the general trend of generalist species occupying more disturbed habitats in fragmented landscapes (Devictor et al., 2008; Sheldon et al., 2010; Tscharntke et al., 2008). The Pycnonotidae was the most dominant family in the oil palm landscape, comprising nine species of bulbuls, which are habitat and dietary generalists (e.g. Aratrakorn et al., 2006). The trend towards lower bird species richness in the forest fragments within oil palm plantation is supported by Arif and MohdAzlan (2014) at Gunung Gading National Park. Here the mixed dipterocarp forest and lower montane forest is surrounded by oil palm plantation with a similar bird diversity. In their study, Arif and Mohd- 
Azlan (2014) recorded 38 species of understorey birds (Completeness ratio $=0.84$ ) which is more than the 34 species (Completeness ratio $=0.68$ ) in the forest fragments in the present study, even though more mist net-hours were deployed in the present study. The considerable difference in species richness between the very large Gunung Gading National Park (5430 ha) and the forest fragments in the present study remains unresolved. However, it is possible that by acting as refugia, the bird density in forest fragments may be greater than that in large contiguous forest stands where an inverse relation between population density and richness could occur and in turn may reduce extinction risk in low diversity communities (McGrady-Steed and Morin, 2000).

Fragments have a large edge to interior habitat ratio and the secondary forest found in the ecotone at the edge supports more bird species that may inflate species richness in fragments (Koh, 2008a). Species richness in forest fragments also can increase for some years after landscape conversion to oil palm plantation, while species-sorting takes place in these refugia, but then equilibrates to lower levels (Tscharntke et al., 2008).

Forest species in this study declined with distance from the edge into oil palm. Although 28 species were detected in oil palm in this study, there was a dramatic decline in forest species with distance from the edge into oil palm $(n=14$ forest species), compared with 15 forest species at the edge and 34 species in the forest interior. The differences in species richness of forest interior species between the two fragments examined in this study, also suggests that species distribution is dependent on the distance between and area and shape of the forest fragments, with little apparent dispersal or movement of forest species through the oil palm matrix.

The Oriental Dwarf-kingfisher was the most abundant species caught in the forest fragments, contrary to the findings of other studies (Sheldon et al., 2010). A plausible reason for this finding is that there is a complex river network in the study area. In forest fragments in mature oil palm plantation, more individuals and greater bird species richness are expected compared to younger oil palm plantation (Cagod and Nuñeza, 2012). Approximately $80 \%$ of the species found at the edge were also found in both habitats, whereas the $50 \%$ to $64.3 \%$ of species in the forest fragments were shared with oil palm plantation. This reinforces the value of the forestplantation ecotone to birds as they appear to use the secondary forest at the edge as a transitional habitat and as a buffer zone.

Forest-dependent insectivorous species were generally lacking in the oil palm plantation. However, some insectivorous species such as flowerpeckers were recorded in the oil palm, probably because they forage on nectar from understorey plants there. By contrast, some insectivorous species, such as the Ashy Tailorbird (Orthotomis ruficeps) were found only in the oil palm plantation. Insectivorous birds such as the Yellow-vented Bulbul, Ashy Tailorbird, Greater Coucal, and Oriental Magpie-robin are important agents of biological control in oil palm plantation against such pests as bagworm (Metisa plana), nettle caterpillar (Setora nitens) and segestes spp. (De Chenon and Susanto, 2006; Koh, 2008b). In addition, owls were more common in the oil palm and may regulate rodent populations in the plantation (Puan et al., 2011). Despite being a forest dependant species, the Reddish Scops Owl was captured in the oil palm plantation at $100 \mathrm{~m}$ and 300 $\mathrm{m}$. This species occurrence in oil palm areas was also observed in a separate study by Amit et al. (2014) in Durafarm Plantation, Betong, Sarawak. Thus, forest fragments serve as reservoirs of species diversity that are important to plantation management.

\section{CONCLUSION}

Our study demonstrates that maintaining bird species diversity, and their associated ecosystem services in oil palm plantations, through conservation of HCV forest patches, reduces the impact of oil palm production on wildlife and creates a more wildlife-friendly industry.

We recommend incorporating buffer zones near $\mathrm{HCV}$ forest areas within the plantation landscape during the next replanting stage. Maintaining secondary forest as well as old-growth forest patches and avoiding the wholesale clearing of all natural vegetation from plantation landscapes is strongly advised. The development of more sustainable oil palm landscapes containing higher levels of biodiversity in existing planted areas could mitigate some of the adverse effects of habitat modification caused by oil palm plantations. Even small forest fragments should not be regarded as of low value, as these fragments can provide habitat for many rare and threatened bird species within a plantation complex. Forest fragments potentially increase the permeability of oil palm plantations for birds and assist in the maintenance of ecosystem functions important to agricultural landscapes, such as pollination, hydrological functions, soil health, seed dispersal and biological control.

\section{ACKNOWLEDGEMENT}

The authors acknowledge the support received from Wilmar International-PBB Oil Palms Berhad, Forest Department Sarawak, Sarawak Forestry Corporation, students and staff from the Faculty of Resource Science and Technology, Universiti 
Malaysia Sarawak. We are grateful to Simon Siburat, Kiaw Che Weng, Chang Sip Woon and Ginny Ng Siew Ling for their ideas and support. We also appreciate precious assistance from John anak Alit, James Wong Tai Hock, Azlan Liman, Levy anak Tan, Isa bin Sait, Trevor Allen anak Nyaseng, Wahap bin Marni, Nasron Ahmad, Shafri bin Semawi, Mohamad Jalani Mortada, Huzal Irwan Husin, Edward Enggu anak Setu, Golan anak Mat and Joanes anak John. Lastly, we would like to thank the anonymous reviewers for their valuable comments that greatly improved our manuscript.

\section{REFERENCES}

Amit, B; Tuen, AA; Haron, K and Harun, M H (2014). Diversity of bird species in the oil palm plantation on peat. Oil Palm Bulletin No.69: 21-26.

Aratrakorn, S; Thunhikorn, S and Donald, P F (2006). Changes in bird communities following conversion of lowland forest to oil palm and rubber plantations in southern Thailand. Bird Conserv. Int., 16: 71-82.

Arif, N A and Mohd-Azlan, J (2014). Diversity of birds captured by mist-netting in the understorey of Gunung Gading National Park, Sarawak, Borneo. Kukila, 17 (2): 42-50.

Azhar, B; Lindenmayer, D B; Wood, J; Fischer, J; Manning, A; McElhinny, C and Zakaria, M (2011). The conservation value of oil palm plantation estates, smallholdings and logged peat swamp forest for birds. For. Ecol. Manag., 262: 2306-2315.

Azman, N M; Latip, N S A; Sah, S A M; Akil, M A M M; Shafie, N J and Khairuddin, N L (2011). Avian diversity and feeding guilds in a secondary forest, an oil palm plantation and a paddy field in riparian areas of the Kerian river basin, Perak, Malaysia. Trop. Life Sci. Res., 22(2): 45-64.

Bibby, C J; Collar, N J; Crosby, M J; Heath, M F; Imboden, C; Johnson, T H and Thirgood, S J (1992). Putting Biodiversity on the Map. International Council for Bird Preservation, Cambridge. 90 pp.

Cagod, B M and Nuñeza, O M (2012). Avian species diversity in oil palm plantations of Agusan del Sur and Compostela Valley, Philippines. AES Bioflux, 4(2): 85-105.

Campbell, N A and Reece, J B (2002). Biology. Sixth edition. Benjamin Cummings, San Francisco, USA. 187 pp.

Carlson, K M; Curran, L M; Anser, G P; Pittman, A M; Trigg, S N and Adeney, J M (2013). Carbon emissions from forest conversion by Kalimantan oil palm plantations. Nat. Clim. Change, 3: 283-287.

Chazdon, R L; Harvey, C A; Komar, O; Griffith, D M; Ferguson, B G; Martínez-Ramos, M; Morales, H; Nigh, R; Soto-pinto, L; Van Breugel, $\mathrm{M}$ and Philpott, $S$ M (2009). Beyond reserves: A research agenda for conserving biodiversity in human-modified tropical landscapes. Biotropica, 41(2): 142-153.

Colwell, R K (2013). Estimates: Statistical estimation of species richness and shared species from samples (Version 9). [Computer software]. http:/ / purl.oclc/ estimates.

Cramb, R A and Sujang, P S (2012). Pathways through the Plantation: Oil Palm Smallholders and Livelihood Strategies in Sarawak, Malaysia. AARES, Australia. 30 pp.

Devictor, V; Julliard, R and Jiguet, F (2008). Distribution of specialist and generalist species along spatial gradients of habitat disturbance and fragmentation. Oikos, 117(4): 507-514.

Edwards, D P; Hodgson, J A; Hamer, K C; Mitchell, S L; Ahmad, A H; Cornell, S J and Wilcove, D S (2010). Wildlife-friendly oil palm plantations fail to protect biodiversity effectively. Conserv. Lett., 3: 236-242.

Edwards, D P; Magrach, A; Woodcock, P; Ji, Y; Lim, N T L; Edwards, F A and Chung, A Y (2014). Selective-logging and oil palm: Multitaxon impacts, biodiversity indicators, and trade-offs for conservation planning. Ecol. Appl., 24(8): 2029-2049.

Edwards, F A; Edwards, D P; Hamer, K C and Davies, R G (2013). Impacts of logging and conversion of rainforest to oil palm on the functional diversity of birds in Sundaland. Ibis, 155: 313-326.

Fitzherbert, E B; Struebig, M J; Danielsen, F; Brúhl, C A; Donald, P F and Phalan, B (2008). How will oil palm expansion affect biodiversity? Trends Ecol. Evol., 23: 538-545.

Forest Stewardship Council (2000). FSC Principles and Criteria. Document 1.2, revised February 2000. http: / www.rgisa.com / file.php / 1/ principles.pdf, accessed on 15 March 2019.

Foster, W A; Snaddon, J L; Turner, E C; Fayle, T M; Cockerill, T D; Ellwood, M D F and Yusah, K M (2011). Establishing the evidence base for maintaining biodiversity and ecosystem function in the oil palm landscapes of South East Asia. Philos. Trans. R. Soc. Lond. B. Biol. Sci., 366: 3277-3291. 
Gilbert, N (2012). Palm-oil boom raises conservation concerns. Nature News, 487(7405): 14.

Gregory, R D; Noble, D; Field, R; Marchant, J; Raven, M and Gibbons, D W (2003). Using birds as indicators of biodiversity. Ornis Hungarica, 12(13): 11-24.

Hammer, O; Harper, D A T and Ryan, P (2001). PAST: Paleontological statistical software package for education and data analysis. Paleontol. Electron., 4(1): 9.

IUCN (2019). The IUCN Red List of Threatened Species. Version 2018-2. http: / / www.iucnredlist.org, accessed on 10 March 2019.

Jennings, S; Nussbaum, R; Judd, N; Evans, T; Iacobelli, T; Jarvie, J; Lindhe, A; Synnott, T; Vallejos, C; Yaroshenko, A and Chunquan, Z (2003). The High Conservation Value Forest Toolkit. First edition. ProForest, Oxford. p. 1-62.

Koh, L P (2007). Potential habitat and biodiversity losses from intensified biodiesel feedstock production. Conserv. Biol., 21: 1373-1375.

Koh, L P (2008a). Can oil palm plantations be made more hospitable for forest butterflies and birds? J. Appl. Ecol., 45: 1002-1009.

Koh, L P (2008b). Is oil palm production really destroying tropical biodiversity? Conserv. Lett., 1: 60-64.

Koh, L P (2008c). Birds defend oil palms from herbivorous insects. Ecol. Appl., 18: 821-825.

Krüger, S C and Lawes, M J (1997). Edge effects at an induced forest-grassland boundary: Forest birds in the Ongoye Forest Reserve, KwaZulu-Natal. S. Afr. J. Zool., 32: 82-91.

Maas, B; Putra, D D; Waltert, M; Clough, Y; Tscharntke, T and Schulze, C H (2009). Six years of habitat modification in a tropical rainforest margin of Indonesia do not affect bird diversity but endemic forest species. Biol. Conserv.1, 42: 2665-2671.

Magurran, A E (2004). Measuring Biological Diversity. Wiley-Blackwell, Oxford. 256 pp.

Mayfield, M M (2005). The importance of nearby forest to known and potential pollinators of oil palm (Elaeis guineensis Jacq.; Areceaceae) in southern Costa Rica. Econ. Bot., 59: 190-196.

McGrady-Steed, J and Morin, P J (2000). Biodiversity, density compensation, and the dynamics of populations and functional groups. Ecology, 81: 361-373.
Miller-Rushing, A J; Primack, R B; Devictor, V; Corlett, R T Cumming, G S; Loyola, R; Maas, B and Pejchar, L (2019). How does habitat fragmentation affect biodiversity? A controversial question at the core of conservation biology. Biol. Conserv., 232: 271-273.

MPOB (2018). Oil palm planted area 2018. <bepi. mpob.gov.my/images / area / 2018 / Area_summary. pdf $>$, accessed on 14 March 2019.

Mulder, C P H; Bazeley-White, E; Dimitrakopoulos, P G; Hector, A; Scherer-Lorenzen, M and Schmid, B (2004). Species evenness and productivity in experimental plant communities. Oikos, 107(1): 50-63.

Myers, N; Mittermeier R A; Mittermeier C G; da Fonseca, G A B and Kent, J (2000). Biodiversity hotspots for conservation priorities. Nature, 403 (6772): 853-858.

Newmark, W D (1991). Tropical forest fragmentation and the local extinction of understorey birds in the Eastern Usambara Mountains, Tanzania. Conserv. Biol., 5: 67-78.

Padoa-Schioppa, E; Baietto, M; Massa, R and Bottoni, L (2006). Bird communities as bioindicators: The focal species concept in agricultural landscapes. Ecol. Indic., 6: 83-93.

Pardo, L E; Roque, F D O; Campbell, M J; Younes, N; Edwards, W and Laurance, W F (2018). Identifying critical limits in oil palm cover for the conservation of terrestrial mammals in Colombia. Biol. Conserv., 227: 65-73.

Peh, K S H; Sodhi, N S; de Jong, J; Sekercioglu, C H; Yap, C A M and Lim, S L H (2006). Conservation value of degraded habitats for forest birds in southern Peninsular Malaysia. Divers. Distrib., 12: 572-581.

Potts, J R; Hillen, T and Lewis, M A (2016). The 'edge effect' phenomenon: Deriving population abundance patterns from individual animal movement decisions. Theor. Ecol., 9(2): 233-247.

Powell, L L; Wolfe, J D; Johnson, E I; Hines, J E; Nichols, J D and Stouffer, P C (2015). Heterogeneous movement of insectivorous Amazonian birds through primary and secondary forest: A case study using multistate models with radio telemetry data. Biol. Conserv., 188: 100-108.

Puan, C L; Goldizen, A W; Zakaria, M; Hafidzi, M N and Baxter, G S (2011). Absence of differential predation on rats by Malaysian barn owls in oil palm plantations. J. Raptor Res., 45(1): 71-78. 
Sekercioglu, C H (2006). Increasing awareness of avian ecological function. Trends Ecol. Evol., 21: 464471. DOI:10.1016/j.tree.2006.05.007.

Sekercioglu, C H; Daily, G C and Ehrlich, P R (2004). Ecosystem consequences of bird declines. Proc. Natl. Acad. Sci. USA, 101: 18042-18047.

Şekercioglu, C H; Ehrlich, P R; Daily, G C; Aygen, D; Goehring, D and Sandi, R F (2002). Disappearance of insectivorous birds from tropical forest fragments. Proc. Natl. Acad. Sci. USA, 99(1): 263-267.

Sheldon, F H; Styring, A and Hosner, P A (2010). Bird species richness in a Bornean exotic tree plantation: A long-term perspective. Biol. Conserv., 143: 399-407.
Srinivas, A and Koh, L P (2016). Oil palm expansion drives avifauna decline in the Pucallpa region of Peruvian Amazonia. Glob. Ecol. Conserv., 7: 183-200.

Tscharntke, T; Sekercioglu, C H; Dietsch, T V; Sodhi, N S; Hoehn, P and Tylianakis, J M (2008). Landscape constraints on functional diversity of birds and insects in tropical agroecosystems. Ecology, 89: 944-951.

Turner, E C and Foster, W A (2009). The impact of forest conversion to oil palm on arthropod abundance and biomass in Sabah, Malaysia. J. Trop. Ecol., 25: 23-30.

Yahner, R H (1988). Changes in wildlife communities near edges. Conserv. Biol., 2: 333-339. 